ACTA UNIVERSITATIS LODZIENSIS

FOLIA LITTERARIA POLONICA 4(30) 2015

http://dx.doi.org/10.18778/1505-9057.30.08

Sylwia Grzeszna*

\title{
Dlaczego Kain? Motyw sacrum we wczesnych wierszach Marcina Świetlickiego
}

\author{
Białe przepaście. / Gdybyś coś / naprawdę \\ kochał / lub był przywiązany / naprawdę: nie \\ byłoby ich. \\ Ręce i stopy są pełne spadania / - co trzyma \\ mnie za język? \\ (Białe przepaście, 1983, ZK¹1)
}

Jedna z pierwszych myśli związanych z sacrum ${ }^{2}$ przyjmuje w poezji autora Zimnych krajów postać pytania retorycznego: „Co to / za światło, które można opowiedzieć, które / ma regulamin? Co to / za wierni, którym nie wystarczy / ten nieprzerwanie wieczny pocałunek bez ust?" (Zły ptak 1986, ZK 29). Ironia pytającego, zbulwersowanego oczekiwaniami interlokutora-czytelnika, nie zagłusza wiary $\mathrm{w}$ istnienie niewyrażalnego wymiaru egzystencji. Być może wiara to za duże słowo w przypadku autora Pieśni profana, pewnie należałoby raczej mówić o pragnieniu lub po prostu przekonaniu. Jednak każdej z propozycji jako nazwie określonego rodzaju stanu lub czynności (myślałam jeszcze o poszukiwaniu) grozi nieprzystawalność do projektu, w którym wszystko jest jednocześnie nieoczywiste i nieprzypadkowe. Dlatego wybieram słowo najbliższe (wyraz

\footnotetext{
* Mgr, Uniwersytet Łódzki, Wydział Filologiczny, Instytut Filologii Polskiej, Katedra Literatury Polskiej XX i XXI wieku, ul. Pomorska 171/173, 90-236 Łódź, e-mail: s.chrostowska@poczta.onet.pl

${ }^{1}$ Podaję datę (jeśli jest), skrót tomu oraz stronę. Korzystam z pojedynczych zbiorów, do Wierszy sięgam po utwory wcześniej niedrukowane. Wykaz skrótów:

ZK - Zimne kraje, Wydawnictwo Lampa i Iskra Boża, Warszawa 2002.

S - Schizma, Wydawnictwo Czarne, Czarne 1999.

TP - Trzecia połowa, Wydawnictwo a5, Poznań 1996.

$\mathrm{Cz}$ - Czynny do odwołania, Wydawnictwo Czarne, Wołowiec 2001.

W - Wiersze, Wydawnictwo EMG, Kraków 2011.

2 Termin sacrum rozumiem jako ,hasło wywoławcze dla różnorodnych elementów sakralnych, związanych bliżej z religijną postawą, z tym, co nadnaturalne"; S. Sawicki, Sacrum w literaturze, w: Sacrum w literaturze, red. J. Gotfryd, M. Jasińska-Wojtkowska, S. Sawicki, Wydawnictwo KUL, Warszawa 1983, s. 14.
} 
„wierni” konotuje wiarę w coś), mając świadomość powierzchowności takiego założenia. Wierni, którym nie wystarcza „nieprzerwanie wieczny pocałunek bez ust" są w zasadzie niewiernymi, a głos protagonisty Marcina Świetlickiego bliższy jest mówiącym o zwątpieniu niż tym, którzy karmią się nadzieją:

\author{
Zły ptak \\ To pewne: ten ptak - sroka \\ próbuje mnie okrążyć \\ i osaczyć, dzień w dzień \\ zatacza coraz mniejsze kółka \\ i skrzeczy: buddyzm, materializm, \\ literatura, pieniądze, w imię Ojca i Syna, \\ skrzeczy: odpowiedzialność, skrzeczy: wychowanie \\ - i wszystko inne takie. Co to \\ za światło, które można opowiedzieć, które \\ ma regulamin? Co to \\ za wierni, którym nie wystarczy \\ ten nieprzerwanie wieczny pocałunek bez ust? (1986, ZK 29)
}

Charakterystyczna dla całej twórczości Świetlickiego interpretacja świata i wartości w nim kultywowanych jako nieustannie czyhających na człowieka zagrożeń zderza się z niezwykle subtelnym opisem miłości. Czy można inaczej określić uczucie łączące nieprzewidywalność (nie ma regulaminu) i niezmienność (nieprzerwanie wieczny pocałunek)? Uczucie, jak wiadomo, jest czymś innym niż jego opis. Zwykle to, co uczucie w sobie łączy, jego opis próbuje podzielić, rozłożyć pod mikroskopem odczytywania. Wydaje się, że świadomość konieczności rozdzielenia doświadczenia, także religijnego, od jego językowej referencji nie opuszcza autora Pieśni profana. Może dlatego ucieka on jako poeta przed wszelkim dookreśleniem? W każdym razie w przypadku Świetlickiego bezpieczniej jest mówić o próbowaniu możliwości języka niż o projekcie zakładającym jasno określony cel.

Bohater wierszy Świetlickiego stwierdza, że nie chce być jednym z wielu, którzy nie odróżniają subtelnej muzyki od skrzeku, dają się uwieść złemu ptakowi powinności... Czy mu się to udaje? „Czemuś jestem wierny / więc czuję się jak u siebie" - mówi podmiot Pięciu wierszy religijnych, wyjaśniając swoją obecność w rynku rodzimego miasta w czasie procesji Bożego Ciała. Obwarowane zaimkami wyznanie nie powiększa wiedzy o podmiocie, zostawia za to furtkę bezpieczeństwa dla mówiącego. Czytelnik pozostaje zaciekawiony, a piszący może cieszyć się przynajmniej namiastką wolności, jaką daje nieprzewidywalność.

Wolność taka, jak każda inna, ma swoją cenę. Może być nią trudność w porozumieniu z odbiorcą, zwodzonym wciąż nowymi odsłonami ,ja” lirycznego, albo - gdy weźmiemy pod uwagę najwyższą stawkę - utrata autentyczności. Niektórzy 
twierdzą, że Świetlickiemu nie zależy na budowaniu relacji z czytelnikiem³ ${ }^{3}$ Podobnej tezie zdaje się jednak przeczyć konsekwencja, z jaką poeta sięga do symboliki rodzimej (i tylko rodzimej ${ }^{4}$ ) religijności. Przetwarzanie motywów znanych i ważnych z chrześcijańskiego punktu widzenia może ułatwiać porozumienie w świecie wyrosłym na wartościach chrystianizmu, nawet jeśli nie służy budowaniu tych wartości.

Istnieje wiersz „do pary” dla Zlego ptaka, którego daty powstania nie znamy, a który poeta umieścił w tomie wydanym cztery lata po debiucie:

Poniechana pielgrzymka

Oto ruszają wszystkie katarynki, oto i w dłoniach pęcznieją paciorki, oto i brud zaświecil, oto i ja kalam

i kala razem ze mną niewidzialny chór.

Nadużywanie słowa sacrum ma jednakowoż ten sam ciężar, co szczeniackie puszczanie bąków w salonie.

A kto wymyślił salon?

A kto wymyślił sacrum?

A kto się otarł o grzech?

A kto się o grzech otrze?

I nie ma czego chronić

oprócz tej wysepki, która się zmniejsza co dzień, ale się nie zmniejszy

ostatecznie, bo ostatecznie wiadomo, co jest

i póki my

póki my piszemy. (TP 40)

${ }^{3}$ Por.: J. Orska, Liryczne narracje. Nowe tendencje w poezji polskiej 1989-2006, Wydawnictwo Universitas, Kraków 2006, s. 116 i 132.

${ }^{4} \mathrm{Na}$ jednym ze spotkań autorskich Marcin Świetlicki przyznaje, że katolicyzm pozostaje jedyną religijną inspiracją dla jego twórczości. Poeta uważa, że poszukiwania na terenie innych religii niż ta, w której został wychowany byłoby sztuczne. Spotkanie z Marcinem Świetlickim. Prowadzenie Irek Grin. V Festiwal Puls Literatury. Łódź, 4 grudnia 2011. 
Pierwszy wers wiersza („Oto ruszają wszystkie katarynki”) można odnieść do praktykowania wszelkich ideologii (w Zlym ptaku pojawił się m.in.: buddyzm, materializm), choć tytuł wiersza sugeruje zawężenie krytyki do przejawów religijności. Działania zbiorowe podejmowane z pobudek religijnych określa w utworze słowo oznaczające nieużywany dziś instrument muzyczny, do którego obsłużenia nie potrzeba żadnych umiejętności muzycznych. Ktoś kręci korbką i wymyśla słowa: salon, sacrum, grzech. Ktoś inny (?) słucha melodii katarynki - skrzeku złego ptaka. Nic nie pozostaje z tego, co ,przemieli” katarynka - to powszechne kalanie i kajanie jednocześnie. Bohater liryczny wiersza, ukryty wyjątkowo pod zaimkiem sygnalizującym liczbę mnogą, ponownie stawia się ponad niegodnym uwagi Boga i ludzi tłumem. W tym utworze wywyższa go świadomość istnienia pewnej malutkiej wysepki, kolejnej samotnej oazy - na morzu literatury czy religijności? „Wysepką” może być literatura rozumiana jako pisanie cieszące się nieprzewidywalnością, ostatni bastion twórczości nieuwarunkowanej ideologicznie. W wierszu pobrzmiewa jeszcze echo buntu przeciw klasycznym obowiązkom poezji („Póki my ${ }^{5}$ piszemy” w miejsce słów hymnu narodowego), ale na plan pierwszy wysuwa się idea „samostwarzania się" projektami życia i tworzenia. „Wysepka” może po prostu oznaczać wszystko, co piszący pragnie ukryć przed światem, czym nie zamierza dzielić się nawet ze swoim czytelnikiem. Może nią być także badanie granic języka - próba „rozpisania" przekonań religijnych w języku poetyckim otwartym, a poniekąd i programującym różne możliwości odczytania. Eksperyment taki można potraktować jako ,grę z autentykiem”, stylizację, w której dominująca rola przypada uwarunkowaniom retorycznym?

Czy Świetlicki tylko projektuje pewne wrażenia religijne, wrzuca tradycyjne formy w wir awangardy, by wzbogacić swą twórczość, zbudować napięcie w wierszu? A może prowokacyjne gesty autora Zimnych krajów wychodzą poza poszukiwanie własnego dyskursu, a ich gwarantem pozostaje jakaś metafizyczna nadzieja?

Wydaje się, że historia opowiadana przez bohatera wierszy Świetlickiego posiada wyraźny moment zapalny, a zarazem ogniwo, które spaja powracające wątki. Piszącego napędza poczucie winy, które można utożsamiać z grzechem,

${ }^{5}$ Wszystkie podkr. - S.G.

${ }^{6} \mathrm{O}$ tworzeniu prywatnych mitologii przez Jacka Podsiadłę, Marcina Świetlickiego oraz Eugeniusza Tkaczyszyna-Dyckiego pisał Robert Mielhorski; zob.: tenże, Tendencje teatralizacyjne i modulacyjne w poezji najnowszej (E. Tkaczyszyn-Dycki, M. Świetlicki, J. Podsiadto), w: Nowa poezja polska. Twórcy - tematy - motywy, red. T. Cieślak, K. Pietrych, Księgarnia Akademicka, Kraków 2009, s. 335-350. W twórczości omawianych poetów badacz wyróżnia następujące mity: katastroficzna wizja współczesności (np. supermarket-katedra), zagłada Arkadii, ruchomy obraz i ruchome znaczenie symboliki domu, powrót do dzieciństwa, bunt wobec narzuconych norm $\mathrm{i}$ instytucji, tendencje epistemologiczne u podstaw poetyckiej referencji.

${ }^{7}$ J. Orska, dz. cyt., s. 31-32. 
nieczystością, a także niezadowoleniem z siebie i koniecznością nieustannego żalenia się w tekście. Czy jest to jedynie żal wynikający z przekonania zawartego w przysłowiu: „Zły to ptak, co własne gniazdo kala”?

$$
\text { * } \quad * \quad *
$$

Za początek opowieści autora Zimnych krajów można uznać trzy wiersze, odczytywane zgodnie ze schematem dobrego wypracowania. Wstęp, Rozwinięcie, Zakończenie to pochodzące $\mathrm{z}$ różnych tomików utwory, które mogły powstać w podobnym czasie, co sugerują tytuł i spójność tekstów ${ }^{8}$. W otwierającym debiutancki tomik utworze, sygnowanym datą narodzin poety, moment inicjacji z rzeczywistością zostaje całkowicie podporządkowany symbolice religijnej:

\section{Wstęp}

Dam mu na imię Abel - powiedział ten obcy

człowiek, którego potem tak straszliwie trudno

będzie nazwać ojcem [...]. DAMY mu tak na imię - podkreśliła matka, a on się skrzywił - to on zdecydował a ona tylko powinna przytaknąć.

\section{$[\ldots]$}

oboje byli nadzy i wstydzili się.

Zaskroniec pełzał poprzez ogród i jadł kurz i piasek, a ojciec ojca kaszlał i krzyczał za ścianą w obcym języku klątwy, a radio trzeszczało, trzeszczało i huczało niczym miecz ognisty.

Na nocnych polach i podwórkach nocnych krążył nie istniejący starszy brat i śmiał się.

Wiosna. $[\ldots]$

Będziemy obserwować postępy ciemności. (1989, ZK 3)

Quasi-biblijna charakterystyka opisanej w tekście rodziny zachęca do lektury według zasad schematu powieści kryminalnej. Opowieść protagonisty Świetlickiego, czytana dosłownie i przenośnie, podsyca nasz niepokój. Chcielibyśmy

${ }^{8}$ Marcin Świetlicki przyznaje, że pisze bardzo dużo, a do poszczególnych tomików wybiera spośród wielu wierszy. Być może poeta celowo rozproszył utwory, które zestawione tworzą spójną całość. Spotkanie z Marcinem Świetlickim. Prowadzenie Irek Grin. V Festiwal Puls Literatury. Łódź, 4 grudnia 2011. Wyznanie poety potwierdzają utwory niedrukowane, opublikowane w Wierszach zebranych. 
automatycznie zaspokoić ciekawość, poznać źródło osobliwych relacji w rodzinie Abla; zrozumieć, czemu ojciec ojca krzyczy klątwy w takt trzeszczącego radia. " [...] kim jest «ojciec ojca», w jakim języku i przeciw komu rzuca swoje klątwy?" - dopytuje na przykład Tomasz Kunz, zastanawiając się nad znaczeniem motywu genezyjskiego w twórczości Świetlickiego9. Jest jeszcze brat, paradoksalnie: starszy, choć nieistniejący; nieistniejący, ale śmiejący się „na nocnych polach i podwórkach nocnych". Domyślamy się przecież imienia kolejnej postaci, niejasna pozostaje tylko rola, jaką odgrywa Kain.

Zadziwiające, w jak wiele niewiadomych można wyposażyć historię opartą na znanym, wielokrotnie przetwarzanym motywie. Spójrzmy na najbardziej wyrazistą, wysuwającą się na plan pierwszy opozycję światło-ciemność. Nadejście nocy zapowiada, że światłość będzie musiała ustąpić ciemności. Można postawić pytanie, czy światłość ma jakiekolwiek znaczenie w kreowanym w wierszu świecie - podmiot mówi bowiem o wieczorze, wskazuje na „nocne pola i podwórka nocne”. Zapowiedź postępów ciemności można odczytać także jako usuwanie światła, którego resztki symbolizuje trzask i huk radia porównany do miecza ognistego. Hałas ,płonącego radia” mógłby przypominać o wygnaniu. To tak, jakby świat kreowany przez autora Schizmy był związany z trudną, poarkadyjskią rzeczywistością, istniejącą niejako za karę - zamiast lepszego świata, ale bez zerwania łączności z arkadią. Dopóki radio huczy niczym miecz ognisty, istnieje pamięć o raju. W takim ujęciu obserwowanie postępów ciemności stawałoby się znacznie mniej groźne.

„Oto się ciemność powoli rozszerza / i wchodzi wszędzie. I wewnątrz wszystkiego / maszeruje jak robak" - czytamy w pierwszym wersie Rozwinięcia. Wieczór ze Wstępu przeradza się w północ, opowieść pozornie przenosi się na zewnątrz (nocny spacer po mieście) i pozornie podmiot-obserwator wchodzi w rolę ściganego, przybysza z innego miasta zagrożonego atakiem miejscowych:

[...] Resztki deszczu, północ.

Pies sika, a ja mrużąc oczy wypatruję wroga:

gdzieś jest, w tej tutaj pustce, w tym

czasie, skądś tu idzie, lecz na razie jednak

ma twarz kamienic i drzew, gdzieś tu musi być,

ma mnie w swoich lornetkach, na polowych mapach,

wewnątrz. (S 33)

${ }^{9}$ T. Kunz, Postępy ciemności, w: Mistrz świata. Szkice o twórczości Marcina Świetlickiego, red. P. Śliwiński, Wydawnictwo Wojewódzkiej Biblioteki Publicznej i Centrum Animacji Kultury w Poznaniu, Poznań 2011, s. 12. 
To „wewnątrz” okazuje się słowem-kluczem Rozwinięcia. Wewnątrz wiąże się z nocą, jej środkiem, dotyczy ciemności, która „maszeruje wewnątrz wszystkiego”. Ciemność sygnuje kreowaną przestrzeń zewnętrzną (,[w]yczerpanym światłem / latarnie zdolne są oświetlić tylko / siebie nawzajem”), ale jej źródłem jest przestrzeń wewnętrzna. Wróg nie może ukrywać się w mieście, którego nie ma. Zarówno czas, jak i miejsce budowane są w utworze przez zaimki nieokreślone; zdarzenie zaś, na które się czeka, zostaje unieruchomione, zatrzymane w „tym” czasie, zaprzeczone (,lecz na razie jednak”). Wróg musi więc czaić się wewnątrz, przygląda się przecież z bliska („ma mnie na swoich lornetkach”). Dlaczego wypowiada wojnę („na polowych mapach”) i sprawia, że zagrożony zaczyna się tłumaczyć?

Nie jestem zdrajcą, lecz oczarowania rozczarowały. Jadąc tu pociągiem dostrzegałem przestrzenie stokroć potężniejsze i widuję je jeszcze czasami we śnie,

[...]. Zawsze jednak jest jeszcze jakieś inne miasto, ponad tym. Zawsze jest coś ponad tym.

Nie bez znaczenia wydaje się umiejscowienie tekstu w zbiorze. Wiersz pojawia się w Schizmie po utworze Znamię (S 13), a przed tekstem zatytułowanym $M$ - morderca (S 35). Podmiot Świetlickiego zostaje przedstawiony jako ktoś, kto bardzo troszczy się o podtrzymanie wizerunku winowajcy, ale i dba o urozmaicenie tonu samooskarżania się rejestrami wnoszącymi pozór prostoty i przejrzystości. W Zakończeniu najważniejszy element quasi-biblijnej opowieści zajmuje przeznaczone mu miejsce:

\section{Zakończenie}

Nie opiszę wszystkiego. Przyszło, zabroniło.

Dla pewności zostało, kontroluje, bywa.

Powoli opuszczamy się

W szczelinę.

\section{Ciągnę wszystko ze sobą.}

Dam mu na imię Kain. (TP 7)

Kaina łatwo powiązać z uosobionym, (a nawet odpowszechnionym) ,wszystkim", które kontroluje piszącego. Wydaje się, że Świetlicki celowo ułożył wiersz tak, by można było go odczytywać na dwa sposoby. W kontekście przywołanego schematu utwór należałoby podzielić na dwie części. Pierwszą można interpretować jako zapis walki piszącego z materią rzeczywistości, czyli wszystkim, co 
można opisać. Druga rejestruje powtórzenie gestu ojca ze Wstępu. Przy takiej interpretacji nie dziwi wybór imienia dla nowo narodzonego:

Podkreślona zostaje w ten sposób - pisze Tomasz Kunz - nieuchronna, bezwyjściowa cykliczność, powtarzalność opowiedzianej historii. Wybór imienia dla poczętego dziecka daje się [...] odczytać jako pełna rezygnacji zgoda na nieprzerwany cykl narodzin i śmierci [...]. Kain okazuje się zatem nie tyle winowajcą, świadomym sprawcą zła, ile bezwolnym posłańcem i narzędziem ciemności, która pozostaje bezimienna i nienazywalna ${ }^{10}$.

Przywołanie symbolu biblijnego winowajcy okazuje się niezbędne dla opowiadanej historii. Genezyjska klisza pozwala uruchomić najbardziej „nośne” motywy: zdradę, zabójstwo, wykluczenie - wszystko, co ułatwia podtrzymywanie kontaktu z odbiorcą. Wiersz rozpada się na części, które można ustawić na jednej płaszczyźnie. Kain Świetlickiego może być jednocześnie sensem wszystkiego, o czym traktuje opowieść autora Schizmy, i imieniem nowo narodzonego - elementem nietrudnej układanki. Trzeba dodać, że nadawanie imienia pierworodnemu nie było łatwe, a dokonany wybór podważa jego arbitralność. „Nie umiemy / dać mu imienia” - czytamy w ostatnim wierszu ze Schizmy - „No bo to zupełnie niemożliwe. Najprościej / byłoby go nazwać Chłopczykiem / lub Zajączkiem / albo Zasranym Kaftanikiem. Jest. Pojawił się / w miejsce Rzeczywistości” (S 65).

Nadawanie imienia, w Piśmie świętym równoznaczne z powołaniem do istnienia, u Marcina Świetlickiego jest sygnowaniem istniejącej rzeczywistości zużytym, niewiele wnoszącym znakiem. Imię „Kain” mógłby zastąpić „Chłopczyk”, „Zajączek” albo „Zasrany Kaftanik”, co nie zmieniłoby roli, jaką wybrał dla nowo narodzonego protagonista Świetlickiego. Pojawienie się Kaina w miejsce zajmowanej przez ciemność rzeczywistości to rozwiązanie najprostsze i zarazem najbardziej czytelne, choć wieloznaczne.

Maszerującego z impetem robaczka ciemności można utożsamić ze śmiercią, której widmo pojawia się, a nawet warunkuje rozpoczęcie narracji u autora Zimnych krajów. Powołując się na rozpoznania Mariana Stali, pisze Kunz:

Mowa tu zatem o podmiocie zarażonym tą ostateczną negatywnością, którą już wkrótce zaczyna odkrywać nie tylko wokół siebie, ale także w sobie, i która także i jego uczyni ostatecznie „kimś, kto nie daje się nazwać”, kimś wywłaszczonym z własnej tożsamości, ,niepodobnym do odbicia w lustrze” [...], a więc równie widmowym, co jego nienazwany starszy brat ${ }^{11}$.

\footnotetext{
${ }^{10}$ T. Kunz, dz. cyt., s. 26.

${ }^{11}$ Tamże, s. 13. Por. także: M. Stala, Druga strona. Notatki o poezji współczesnej, Wydawnictwo Znak, Kraków 1997, s. 193.
} 
W sytuacji, kiedy ciemności-śmierci nie można się raz na zawsze przeciwstawić („Będziemy obserwować postępy ciemności”), dobrze mieć możliwość znikania, bycia i niebycia jednocześnie. Podmiot, którego nie daje się nazwać, wydaje się wolny, a wybór religijnej kliszy do przetwarzania świata długo pozwala mu snuć opowieść. Kiedy analogia ciemności do śmierci wyczerpuje się, autor Niskich pobudek rzuca ,koło ratunkowe” (komu?) w postaci asocjacji pogodowych.

W jednym z wierszy z pierwszego tomu Świetlickiego podmiot ogłasza przedwczesną jesień życia ${ }^{12}$ oraz zaznacza, że podjął już przygotowania do nadchodzącej zimy ${ }^{13}$. Wszystkie asocjacje związane $\mathrm{z}$ najzimniejszą porą roku chłód, ciemność, zatrzymanie życia - nabierają stopniowo, ale systematycznie decydującego znaczenia w kreowanym świecie - Zimnych Krajach. Metafora zawarta w tytule debiutanckiego tomu Świetlickiego wydaje się dobrze przemyślanym sposobem obrazowania ${ }^{14}$. Zima sprzyja izolacji, a z braku ciepłastaje się najbardziej wymownym symbolem śmierci. Z drugiej strony, zima anonsuje wiosnę, daje nadzieję na przechowanie życia - wewnętrznego ciepła w nienaruszonej przez innych postaci. „To mój wewnętrzny narząd bezpieczeństwa / wykluczył wszystko ciepłe” - wyjaśnia podmiot Zimnego miasta - „i dopatrzył się / karygodnych uchybień u wszystkich przychylnych”. Wewnętrzne Zimne Kraje zapewniają schronienie przed męką z powodu uchybień innych i zła świata oraz pozwalają się odczytywać jako pułapka i zapowiedź dalszego cierpienia. Rzeczywistość ograbiona z ciepła utrudnia porozumienie się z innymi. Świat bohatera

12 Por. także wiersz pt. Początek z Wierszy niedrukowanych i rozproszonych, (W), s. 482.

${ }^{13}$ Przytaczam utwór w całości: „Blachy liści na blachę ziemi. / Myszy liści po zwiędłych myszach. / Chłód. Chłód. / Już krwawe szmaty wgrzebane głęboko. / Świeży zimowy jasny w dłoni nóż" (***1981, ZK 10).

Pozbawiony form osobowych tekst dobrze oddaje stagnację świata, w którym dominuje chłód. Obniżenie temperatury następuje gwałtownie i może być odczuwane jako bolesne - uderzenie blachy o blachę wywołuje hałas, który w ciszy odbija się długim echem. Szara rzeczywistość (,„zwiędłe myszy”) zmienia formę na jeszcze smutniejszą, bardziej przygnębiającą (,myszy liści”). Kolejną fazą jest chłód - dojmujące zobojętnienie, które paraliżuje możliwość wyrazu, „zamraża” rzeczywistość w - jak się okaże - ważnej dla Świetlickiego lapidarnej formule. W przytoczonym wierszu ostatnie ślady życia (krwawe plamy nawiązują do przeszłości, w której było życie) znikają zakopane głęboko pod zamarzniętą ziemią. Utwór możemy czytać jako opis „krajobrazu po bitwie” traktowanej bardzo poważnie (,wgrzebane głęboko krwawe szmaty” konotują zranienie, o którym mówiący pragnie zapomnieć). Walka toczy się nadal, ale raczej w charakterze zimnej wojny - „zimowy nóż” w dłoni może oznaczać po prostu „narzędzie walki” piszącego. Zmianę taktyki wojennej sugeruje określenie „świeży”, a także ,jasny”, czyli dający nową nadzieję.

${ }^{14}$ Metafora „zimne kraje” sprawdza się jako sposób obrazowania w całej dotychczasowej twórczości poety, a w ostatnich zbiorach - Muzyce środka i Niskich pobudkach zyskuje szczególną konfirmację. „Zimne kraje” jako metafora rzeczywistości organizują w sumie około pięciu lat pracy twórczej Marcina Świetlickiego. Przywiązanie autora do tego terminu zostało uwydatnione poprzez jego powielanie w tytułach trzeciego i ósmego zbiorku, odpowiednio jako Zimne kraje 2 i Zimne kraje 3. 
wierszy Świetlickiego kurczy się najpierw do czterech ścian pokoju znanego ze Schizmy ${ }^{15}$. Później przestrzeń zapewniająca względne bezpieczeństwo maleje do najmniejszych rozmiarów ludzkiego ciała:

Pierwsze kopnięcie

Oczywiście: sentymentalnych wynurzeń nie będzie.

Za oknem Bestia, tramwaje jak czołgi.

W twoim brzuchu pod moją ręką poruszyło się. (23 czerwca 1992, S 58)

Bestia staje się symbolem lęku przed czymś nieokreślonym i nigdy do końca niewypowiedzianym, nienazwanym. Anarchista może trwać w poczuciu winy lub podjąć samotną walkę z niedostrzeganą przez innych Bestią dopiero, gdy sam ułoży obraz odkrytej przez siebie rzeczywistości. Świetlicki wyznacza bieguny kreowanego świata z właściwym dla omawianej twórczości upodobaniem do dzielenia-rozdwajania. Zimne Kraje znajdują oparcie w podstawowej dychotomii chrześcijańskiej: niebo - piekło, chętnie przytaczanej przez poetę w odwróconej kolejności ${ }^{16}$. Świetlicki wiele zapożycza, zarówno z tradycji literatury jak i rodzimej tradycji religijnej. Znanemu od starożytności motywowi zejścia do piekła towarzyszy u autora Pieśni profana modernistyczny wątek choroby. „Piekielna gorączka” każe bohaterowi wiersza Świetlickiego zgłębiać jakąś ,,straszną tajemnicę” („W gorączce przechodziłem przez pokój, namiętnie / otwierałem szufladę, kilka szuflad od razu, / zanurzyć ręce odważnie - odważnie, / ponieważ w każdej z szuflad mógł nagle się znaleźć / odłamek lustra - albo jakaś stara / żyletka ojca"). Przekonanie, że właśnie tajemnica tego, co niebezpieczne i niepewne ułatwi samoidentyfikację („Przypuszczałem, że / jestem wysłany w jakiejś jeszcze / niejasnej misji, którą uświadomię / sobie kiedy urosnę") skutecznie podsyca namiętność poszukującego. „Bramy piekieł” zostają przekroczone, a pokój - dotychczasowy świat - ginie w płomieniach:

\section{Bieguny}

Tak sobie

wyobrażałem piekło: za drzwiczkami pieca

${ }^{15}$ Zofia Zarębianka porównuje ucieczkę Świetlickiego od świata do naśladowania gestu stwórczego z Księgi Rodzaju (Rdz 1, 1-2) i Ewangelii św. Jana (J 1, 1). „U Świetlickiego świat rozpoczyna się - jakby w opozycji do biblijnego opowiadania - od gestu skierowanego ku sobie przez mówiący podmiot tekstu: «Na początku była moja głowa w moich rękach». To przecież tyleż naśladowanie gestu stwórczego, co ukazanie kierunku ucieczki - od złego nieudanego świata ku światu wewnętrznemu, ku sobie, a zarazem od świata zewnętrznego ku narcystycznemu i egotycznemu zapatrzeniu w siebie". Z. Zarębianka, Rzeczywistość i duch(owość) w nowej poezji na przykładzie twórczości pokolenia „bruLionu”, w: tejże, Czytanie sacrum, Instytut Wydawniczy „Maximum”, Kraków-Rzym 2008, s. 94.

${ }^{16}$ Por. wiersz pt. Rajenie: „Nie ma już pór roku. / Jest piekło-niebo. / Niebo-piekło” (Cz 37). 
rozżarzające się kształty, już nie do poznania, różne kolory płonięcia, przed piecem umiałem wytrzymać dłużej niż przed telewizorem.

Czułem się dużym właścicielem wszystkiego

wrzucając poprzez drzwiczki węgiel w kształcie kuli ziemskiej,

patrząc jak płonie, gorączkując $\mathrm{z}$ tego powodu.

$[\ldots]$

Teraz - gdy mieszkam za drzwiczkami pieca

- w zimnie, ciemnościach, kiedy wreszcie jestem

dużym, prawdziwym właścicielem wszystkiego

- patrzę przez uchylone drzwiczki na pokój i widzę

jak się powoli rozżarza, jak popiół

pokrywa szczątki stołu i krzeseł i łóżka. (1988, ZK 4)

Już samo wyobrażenie piekła jako pieca - ciemnego wprawdzie, ale zimnego - umniejsza karzącą rolę inferna. Osobiste piekło wydaje się niemal doskonałym schronieniem. Inferno $\mathrm{z}$ widokiem na wlasny pokój, z takim samym własnym piecem, do którego podmiot wstępuje dobrowolnie, choć trawiony „piekielną gorączką" - czy człowiek potrafił kiedykolwiek stworzyć sobie wygodniejszą rzeczywistość? „Jestem w piekle i nic mi już nie grozi, nic gorszego nie może mnie już spotkać". Nie o piekło jednak chodzi w wierszu, ale o samą śmierć, traktowaną jako przejście $\mathrm{z}$ jednego etapu życia do drugiego. Utwór można odczytywać jako zapis pierwszego umierania przydarzającego się dziecku, które nie potrafi pogodzić się z koniecznością dorastania. Dwa podstawowe określenia rzeczywistości - zimno i ciemno - można traktować u Świetlickiego jako emblematy dorosłości. Nie ma różnych kolorów spalania i szybkich, płynnych zmian kształtów. Jest świat tworzony do tej pory przez dorosłych - to znaczy winnych za obecne w nim zło. „Piekło to my jako dorośli” - mówi „duży prawdziwy właściciel wszystkiego", tak jakby wierzył, że gestem odtrącenia dorosłości można skazać trudny do zniesienia świat na zagładę.

Jedynym przewodnikiem po czeluściach piekielnego pieca jest „duży prawdziwy właściciel wszystkiego", co ogranicza rzeczywistość do osamotnionego podmiotu - demona (spalenie węgla - kuli ziemskiej wzmacnia ten obraz). Wydaje się, że Świetlickiemu bliżej niż do Dantejskiej wizji piekła ${ }^{17}$ jest do sezonowych wycieczek po infernalnych czeluściach w stylu Rimbauda. Kluczowym

${ }^{17}$ Oto Mieszkaniec Zimnych Krajów utknął w ostatnim, dziewiątym kręgu piekła, najpewniej w jednym z podokręgów - Kainie przeznaczonym dla zdrajcy rodzin i bliskich. Wszystko sprowadzałoby się wówczas do poczucia winy z powodu zdrady - siebie, bliskich, swojej twórczości... Dziewiąty (ewentualnie piętnasty, licząc ilość poetyckich zbiorów) infernalny krąg zamykałby jednak perspektywę dalszych duchowych „wycieczek”. Por.: D. Alighieri, Boska komedia, Wydawnictwo Greg, Kraków 2009, s. 116. 
staje się motyw choroby, którą Świetlicki pielęgnuje w całej twórczości, a szczególnego znaczenia nadaje jej w Muzyce środka. Analogią do ,piekielnej gorączki” Mieszkańca Zimnych Krajów jest u Rimbauda, jak pamiętamy, szaleństwo. „Igranie z obłędem"18 traktowane jest przez autora Sezonu w piekle jako źródło tworzenia:

Przywykłem do zwyczajnej halucynacji: z największą łatwością widziałem meczet w miejsce fabryki, szkołę doboszów prowadzoną przez anioły [...]. Później objaśniałem swoje magiczne sofizmaty halucynacją słów! W końcu uznałem nieporządek mojego umysłu za uświęcony ${ }^{19}$.

Sezon $w$ piekle czytany jako zapis drogi odbywanej w rytm pór roku rozpoczyna się podobnie jak u Świetlickiego: ,,...] wiosna przyniosła mi okropny śmiech idioty" ${ }^{20}$. Potem następuje lato, zmiana nie odnotowana przez obu poetów. U Rimbauda najcieplejsza pora roku wiązałaby się z samą wędrówką po piekle, jesień pojawia się dopiero w Pożegnaniu, w którym jest też mowa o lęku przed zimą ${ }^{21}$.W Świetlickiego opowieści o dorastaniu lato byłoby synonimem dzieciństwa, jesień - walką z piekłem dorosłych, zima - pozornym przejściem na stronę zwalczanych. Podmiot Biegunów przedstawia się jako demon, który żali się na swój los, choć sprawuje całkowitą władzę nad własnym piekłem.

Przyjrzyjmy się teraz, w jaki sposób Świetlicki wykorzystuje symbolikę chrześcijańską do zbudowania swojego infernum. Najbardziej wymownym, a także kolejnym wprowadzającym do tematu piekielnej inicjacji, utworem wydaje się wiersz Jonasz:

Młoda zima, bezśnieżnie. Och, dzisiejszy wieczór uczynił z tej ulicy wnętrze wieloryba.

Byłbym nie zauważył lecz w sklepie warzywnym sprzedawano fragmenty podmorskich zarośli

- i neony w tej chwili zaczęły wysyłać mgłę i wilgoć. Kałuże pełne tranu i krwi.

Przy krawężniku znalazłem muszelkę i poczułem, że jestem / trawiony. (1985, ZK 27)

\footnotetext{
${ }^{18}$ Pisze Rimbaud w pierwszej części swojego dzieła: „Wezwałem oprawców, żeby, konając, kąsać kolby ich karabinów. Wezwałem wszystkie plagi, by zadławić się piachem i krwią. Moim bóstwem było nieszczęście. Tarzałem się w błocie, suszył mnie wiatr zbrodni. Igrałem z obłędem". A. Rimbaud., Sezon w piekle. Iluminacje, przekł. A. Międzyrzecki, wstęp J. Hartwig, Wydawnictwo Prószyński i S-ka, Warszawa 1998, s. 15.

${ }^{19}$ Tamże, s. 35, 36.

${ }^{20}$ Tamże, s. 15.

21 „I obawiam się zimy, bo jest porą wygód”; tamże, s. 46.
} 
Utwór przynosi widmo śmierci z jej stałymi u Świetlickiego atrybutami: zimą i wieczorem (względnie - nocą). „«Zostać połkniętym» jest [...] równoznaczne z «umrzeć», «dotrzeć do Piekieł»"22 - pisze Mircea Eliade.

Zimne Kraje są nie tylko wizją piekła „zdemontowanego” (przez „teologów i psychologów głębi" jak chciał Różewicz ${ }^{23}$ ), pozostają także pod wpływem wyobraźni dziecięcej, skłonnej do mnożenia monstrualnych projekcji. Rzeczy powszednie mienią się tu blaskiem niepokojącej dziwności, interpretowanej jako nieustannie zagrażająca człowiekowi. Świetlicki wykorzystuje biblijne symbole zagrożenia: od bestii - kusiciela (jak we Wstępie), który sprowadza śmierć, do bestii - szatana symbolizującego zło i zagładę. Ważnym symbolem zagrożenia jest także Babilon, przywoływany w dwóch biblijnych znaczeniach: w wymiarze realnym (analogie współczesnego świata do starożytnego miasta znanego ze Starego Testamentu) oraz metaforycznym (zapowiedź zagłady jak w Apokalipsie św. Jana). Autor Schizmy chętnie nakłada na pozbawianą odniesień religijnych współczesność kalkę czasu, w którym ważne wydarzenia interpretowane były jako ingerencja Boga w życie ludzi. W jednym z pierwszych tomów powołuje do istnienia starożytny Rzym, utożsamiany w Apokalipsie z Babilonem jako źródłem wszelkiego zła ${ }^{24}$ :

\section{Rzym}

Tu wewnątrz pływa ryba o czerwonych łuskach.

Rośliny rosną w stronę najgłębszej ciemności.

Między palcami woda. I śnię się nie sobie.

Jestem topielcem. Martwym - lecz zależnym

nadal od Rzymu. Moja głowa chwieje

22 „Nie ulega wątpliwości, że ryba, która połyka Jonasza [...], symbolizuje śmierć: jej brzuch wyobraża Piekło". Por. M. Eliade, Mity, sny, misteria, przeł. K. Kocjan, Wydawnictwo KR, Warszawa 1999, s. 272-273.

${ }^{23}$ Por. wiersz Tadeusza Różewicza pt. Brama, w: tegoż, Nożyk profesora, Wydawnictwo Dolnośląskie, Wrocław 2002, s. 31.

${ }^{24} \mathrm{~W}$ Apokalipsie Babilon to nierządnica, która zasiada na szkarłatnej bestii, upija się krwią świętych: „Ma wiele wspólnego ze Smokiem, który jest szatanem i z Bestią, którą jest Antychryst”. Por. Stownik teologii biblijnej, red. X. Leon-Dufour, przekł. K. Romaniuk, Wydawnictwo Pallotinum, Poznań 1990, s. 63. Obraz prostytutki w Biblii stosuje się do bezbożnych miast, a Rzym od czasów starożytnych utożsamiany był z Wielką Nierządnicą z Apokalipsy św. Jana (por. Ap 17, 1-18). Prostytucja w sensie biblijnym to bałwochwalstwo: „Przede wszystkim [...] prostytucją, czyli nierządem, nazywana jest w Biblii wszelka religia pogańska. [...] Prostytutka Roma zasiada nad wieloma wodami. Geograficznie odpowiada to położeniu Rzymu nad rzeką Tybrem i władzy Rzymu nad całym basenem Morza Śródziemnego, dzielącym się na wiele akwenów. Obrazem Rzymu był Babilon, leżący nad rzeką z odnogami i kanałami. Siedzenie sugeruje królowanie. Alegorycznie wody oznaczać mają [...] ludy podlegające Rzymowi [...]. Wody przedstawiały niekiedy w Starym Testamencie ludy i armie [...]". Apokalipsa świętego Jana. Objawienie, a nie tajemnica, oprac. M. Wojciechowski, Edycja Świętego Pawła, Częstochowa 2012, s. 326-327. 
się w lekkich podwodnych podmuchach.

A wewnątrz głowy pływa mała ryba.

Rzym stuka palcem w powierzchnię wody.

Rzym dudni. Jedna z jego córek

zastąpiła mnie kimś, co niezupełnie podobny jest do mnie,

ale mówi do niego posługując się

moim imieniem, nieliczni dali się przekonać,

niemo protestowała tylko jedna wiewiórka.

Pozostawiłem nieporządek, ale

wszystko się uładziło. Rzym sam

poprawił moje akta, przystosował je

do nowej sytuacji, moje wiersze rozdzielił

między poetów Rzymu, bez żadnych problemów

udało się to przeprowadzić.

Czasami tylko stuka palcem w powierzchnię wody

i pyta: „Jesteś jeszcze tam?”.

Rośliny się ruszają, mówią: „Jest, jest”. (S 16)

Spróbujmy naszkicować mapę hipsometryczną świata, po którym oprowadza nas w tym wierszu Mieszkaniec Zimnych Krajów. Najbliższy wzrokowi, oznaczony na mapie kolorem czerwonym byłby Rzym - imperium grzechu, nazwa kraju i jednocześnie miasta ${ }^{25}$. Potem trudna do zinterpretowania powierzchnia, pod którą dopiero rozgrywa się właściwe życie: rośliny rosnące „W stronę najgłębszej ciemności” przekazują Rzymowi wieści o topielcu (który „śni się nie sobie" - jest martwy, lecz nadal zależny od imperium). Jedyną normalność podwodnego świata, rybę o „czerwonych łuskach”, także dopełnia wizja kuriozum - mała ryba pływająca wewnątrz głowy topielca ${ }^{26}$.

Piekło Zimnych Krajów wymyka się zdolnościom rozumienia dorosłych. Dzieciństwo wydaje się też kluczem do zrozumienia drugiej z opisywanych przestrzeni - nieba. Poniżej przytoczone zostały trzy wiersze ze Schizmy (drugi tom) zgodnie z kolejnością, w jakiej zostały ułożone. W pierwszym tekście, zatytułowanym Uniwersytety, wraca motyw inicjacji ze światem, ale w zupełnie nowej odsłonie:

${ }^{25}$ Zarówno starożytny Babilon, jak i starożytny Rzym to jednocześnie nazwy miasta i państwa. Apokalipsa świętego Jana. Objawienie, a nie tajemnica..., s. 328.

${ }^{26}$ W późniejszych wierszach Świetlicki jeszcze dokładniej przenosi biblijną mapę starożytnego świata na grunt współczesności. W jego relacji powszednieją zwłaszcza elementy kultury spychane na margines. Por. fragment utworu Opluty: „Kraków i Nowa Huta. / Sodoma z Gomorą. / Z Sodomy do Gomory / jedzie się tramwajem" (1992, 37 W 24). 
Nie ma się czego wstydzić: chłopiec uczył się

na strychu - każda inna edukacja

nie jest konieczna - odbijał nad ranem

od łóżka - wspinał się po schodach

- zastawiał wejście szafą - pewnym krokiem

szedł przez sam środek strychu - pająki zaś karnie

prężyły się na swoich

wartowniczych punktach.

Chłopiec rozbierał się, stał, wchłaniał.

Poprzez dziurę w dachu przemawiało niebo,

poprzez niebo natomiast przemawiały ptaki,

ptakami przemawiały ręce Boga głuchoniemego.

Wszelka dobroć pochodzi od głuchoniemych. (S 11)

Charakterystyczne, że powściągliwy na ogół poeta, pisze tak uczuciowy wiersz. Bohater utworu wspina się na strych, by z miejsca najbliższego niebu przysłuchiwać się Bogu. Głuchoniemy Stwórca przemawia dziełem swoich rąk - ptakami. Te z kolei kierują uwagę na niebo, zamykając dialog między Bogiem a stworzeniem z dala od tego, co przyziemne. Chłopiec, który stoi na strychu i chłonie nauki płynące z góry (w sensie dosłownym i przenośnym) wydaje się jednym z wtajemniczonych w rytuał dobroci. Czuje, że musi ukryć się przed dorosłymi; wie, że następnym etapem edukacji jest zdjęcie ubrań. Gest ten można odczytywać ,jako symbol szczerości i otwartości, czystości, prawdy i bezbronności”27. Chłonięcie całym sobą można rozumieć także jako najlepszy z możliwych sposobów uczenia się świata - edukację dziecka: naturalną, wolną od nakazów i ograniczeń.

Porozumienie z transcendencją również wydaje się niemożliwe poza obszarem strychu, wyklucza je inny okres życia niż dzieciństwo, wreszcie - jest aktem pozawerbalnym. Jak pamiętamy z innego wiersza, droga „od litery do Boga” jest „upiornie długa i prawie niemożliwa”, szybko może ją pokonać tylko człowiek podporządkowany z góry narzuconym regulaminom (Dla Jana Polkowskiego 1988, ZK 54). Możemy jedynie przypuszczać, że Mieszkaniec Zimnych Krajów podjął trud tego wyzwania. W ostatnich zbiorkach zdradza, że jest ciągle w „połowie drogi” (mówi o sobie: ,jestem odwrócony, odwrotny”, mogę wziąć przepustkę z piekła, ale tylko na dwa dni - Dwa dni wakacji, MŚ 44).

${ }^{27}$ Por.: J. Borowiec., Rozkopany grób. (Kilka uwag o śmierci zapisanej w wierszach M. Świetlickiego), w: Mistrz świata..., s. 49. Autor ukazuje korelacje Uniwersytetów z innymi wierszami o strychu, konstatując, że strych jako miejsce dziecięcej inicjacji ze światem, staje się dla Świetlickiego „bezpiecznym i magicznym zaciszem, do którego bohater jednego z wierszy będzie w swoich wspomnieniach udawał się w daleką podróż, mijając codzienność miasta, aby "zamknąć się tam z kilkoma przedmiotami» (Niedziela, przed potudniem, ZK 63)"; tamże, s. 50. 
Obok Uniwersytetów znajduje się w Schizmie Piosenka z piwnicy:

Dno piwnicy jest wybrukowane w ten sam sposób co niebo, ale w piwnicy rodzą się jedynie białe i ślepe zwierzęta.

Jeżeli się bez obaw włoży rękę w sam środek butwiejących resztek - można namacać maleńkie serduszko, wiecznie poruszający się początek.

Wielki hałas na górze. Na piętrach dzisiaj święto. A tutaj - w półmroku nie ma święta. Przez piwniczne okno widać tylko podkute buty. (S 12)

Nagłe przejście z oświetlonego światłem dnia strychu (chłopiec wkradał się na strych „nad ranem”) do ogarniętej półmrokiem piwnicy sugeruje, że w kreowanej przez Świetlickiego rzeczywistości wyraźne są jedynie sfery: strych - piwnica, niebo - piekło. To, co pośrodku - dom, codzienność, zwyczajne życie - nie zajmuje uwagi opowiadającego. Można powiedzieć, że zwyczajność istnieje w omawianej poezji przede wszystkim jako podniesiona do rangi niezwykłości. W wierszu powraca pragnienie poznania tego, co niebezpieczne, motyw znany z Biegunów. O ile jednak w Biegunach chodziło o samoidentyfikację podmiotu, o tyle w Piosence z piwnicy przekroczenie granicy pewności ma ułatwić znalezienie początku wszystkiego. „Wiecznie poruszający się początek” - to „maleńkie serduszko”, które bije w samym środku ,butwiejących resztek”. Takie założenie wyklucza udział w świętowaniu „na piętrach”. Ten, który szuka drogi do źródeł, musi pozostać w piwnicy i ograniczyć perspektywę widzenia do sfery ciemności, niepewności (,„podkute buty” wywołują negatywne asocjacje: bohater zostaje w piwnicy, choć boi się „kopniaków” od życia, które wybrał).

Choć „w piwnicy rodzą się jedynie / białe i ślepe zwierzęta”, tylko tam można namacać „,maleńkie serduszko początku”. Szukającym, czyli bohaterem wierszy Marcina Świetlickiego jest poeta, który - ze względu na wykonywaną przez siebie profesję - nie może bezpośrednio wyrazić wiedzy, jaką zdobył „na strychu". Piosenka z piwnicy nawiązuje do wtajemniczenia, którego symbolem jest noc. Wiersz można traktować jako podtrzymanie wizji rozpadu świata na niebo i piekło - przestrzenie wykorzystywane przez autora Trzeciej połowy do snucia opowieści o dramacie dorastania, w którym gubi się zdolność do porozu- 
mienia się z „górą" (Bogiem, transcendencją). Przeobrażanie się chłopca w mężczyznę jest jedną z nielicznych opisywanych przez Świetlickiego metamorfoz, w których można doszukiwać się autentyzmu. Dojrzewanie człowieka, w naturalny sposób powodujące ewolucję stosunku człowieka do idei sacrum, poeta przedstawia analogicznie do opisu postępów choroby niszczącej zarówno ciało, jak i duszę. Świetlicki sięga po kreację poety przeklętego, zdolnego zniszczyć wszelkie konwencje istniejące $\mathrm{w}$ życiu i sztuce, ale gest ten jest napiętnowany poczuciem winy:

\section{Znamię \\ Usta \\ były całością, \\ rozpołowiły się.}

Nieruchomy, na rynku,

$\mathrm{z}$ kartką w dłoni.

Przychodzę na świat

po nocy.

Brat wilk,

siostry z jeziora

przysyłają mi mgłę pod gardło. (S 13)

Ten, który pisze nie może być dobry - doskonałe usta, które „były całością, / rozpołowiły się”. W tym kontekście święto „na górze” mogłoby oznaczać powszechne uznanie, a przecież Mieszkaniec Zimnych Krajów jest poetą, który konsekwentnie czerpie ze sfery ciemności, choć nie zaniedbuje także „drugiej strony".

Protagonista Świetlickiego, oznaczony znamieniem wykluczenia, idealnie wpisuje się w nakreślony we Wstępie model rodziny. Kain, jak pamiętamy, to starszy brat przedstawiony jako zapowiedź istnienia. Abel, choć młodszy, pojawia się wcześniej w Zimnych Krajach; jest pierwszym istnieniem, pierwszą nazwą, początkiem utożsamianym z tym, co dobre - młodością, niewinnością, dzieciństwem. Niestety, Abel ginie z rąk Kaina, który jest w twórczości Świetlickiego symbolem dorosłości. „Powoli opuszczamy się w szczelinę. / Dam mu na imię Kain" - finalny wers z Zakończenia można odczytywać także jako przejście do etapu dorosłości, która bohaterowi wierszy Świetlickiego narzuciła kolejny proces dojrzewania - ojcostwo. 
Badanie motywu sacrum w poezji autora Schizmy przypomina opisywanie kolejnych sentymentalnych klisz, namiastek strategii wyznania. W miarę jak powielane schematy zużywają się, słabnie kontakt z odbiorcą, w którego Świetlicki nigdy nie wierzył28, ale dla którego od początku rozpisywał role dobra i zła.

\section{Bibliografia}

Alighieri Dante, Boska komedia, Wydawnictwo Greg, Kraków 2009.

Apokalipsa świętego Jana. Objawienie, a nie tajemnica, oprac. M. Wojciechowski, Edycja Świętego Pawła, Częstochowa 2012.

Borowiec Jarosław, Rozkopany grób. (Kilka uwag o śmierci zapisanej w wierszach M. Świetlickiego), w: Mistrz świata. Szkice o twórczości Marcina Świetlickiego, red. P. Śliwiński, Wydawnictwo Wojewódzkiej Biblioteki Publicznej i Centrum Animacji Kultury w Poznaniu, Poznań 2011, s. 47-60.

Eliade Mircea, Mity, sny, misteria, przeł. Krzysztof Kocjan, Wydawnictwo KR, Warszawa 1999. Hutcheon Linda, Ironia, satyra, parodia - o ironii w ujęciu pragmatycznym, w: Ironia, przekł. Krystyna Górska, red. M. Głowiński, Wydawnictwo Słowo/Obraz Terytoria, Gdańsk 2002, s. $165-190$.

Kunz Tomasz, Postępy ciemności, w: Mistrz świata. Szkice o twórczości Marcina Świetlickiego, red. P. Śliwiński, Wydawnictwo Wojewódzkiej Biblioteki Publicznej i Centrum Animacji Kultury w Poznaniu, Poznań 2011, s. 12-18.

Nie wierzę we wrażliwego odbiorcę. Z Marcinem Świetlickim rozmawia Tadeusz Dąbrowski, „Topos" 2003, nr 1-3, s. 96.

Mielhorski Robert, Tendencje teatralizacyjne i modulacyjne w poezji najnowszej (E. Tkaczyszyn-Dycki, M. Świetlicki, J. Podsiadło), w: Nowa poezja polska. Twórcy-tematy-motywy, red. T. Cieślak, K. Pietrych, Księgarnia Akademicka, Kraków 2009, s. 335-350.

Rimbaud Arthur, Sezon w piekle. Iluminacje, przeł. Artur Międzyrzecki, wstęp J. Hartwig, Wydawnictwo Prószyński i S-ka, Warszawa 1998.

Różewicz Tadeusz, Nożyk profesora, Wydawnictwo Dolnośląskie, Wrocław 2002.

Stownik teologii biblijnej, red. Xsavier Leon-Dufour, przekł. Kazimierz Romaniuk, Wydawnictwo Pallotinum, Poznań 1990.

Stala Marian, Druga strona. Notatki o poezji wspótczesnej, Znak, Kraków 1997.

28 „Odbiorca musi być wrażliwy. Nie poznałem nigdy nikogo wrażliwego. Nie wierzę we wrażliwego odbiorcę" - zapewniał poeta w jednym z wywiadów. Nie wierzę we wrażliwego odbiorcę. Z Marcinem Świetlickim rozmawia Tadeusz Dąbrowski, „Topos” 2003, nr 1-3, s. 96. Jednocześnie urzekał odbiorcę, a „[...] urzeczenie czytelnika - jak pisze Linda Hutcheon - zawiera [...] w sobie wymóg współdziałania i współwiedzy czytelnika [...]. Urzeczenie to, rzecz jasna, łatwo może zwrócić się przeciwko czytelnikowi, zawodząc jego oczekiwania [...]; w wypadku ironii można by sobie wyobrazić retorykę urzekania, która mogłaby gwarantować zrozumienie, które z kolei gwarantowałoby włączenie (czy zaspokojenie) czytelnika”. L. Hutcheon, Ironia, satyra, parodiao ironii w ujęciu pragmatycznym, w: Ironia, red. M. Głowiński, przekł. K. Górska, Słowo/Obraz Terytoria, Gdańsk 2002, s. 185. 
Orska Joanna, Liryczne narracje. Nowe tendencje w poezji polskiej 1989-2006, Wydawnictwo Universitas, Kraków 2006.

Sawicki Stefan, Sacrum w literaturze, w: Sacrum w literaturze, red. J. Gotfryd, M. Jasińska-Wojtkowska, S. Sawicki, Wydawnictwo KUL, Warszawa 1983, s. 13-26.

Zarębianka Zofia, Rzeczywistość i duch(owość) w nowej poezji na przykładzie twórczości pokolenia „,bruLionu”, w: tejże, Czytanie sacrum, Instytut Wydawniczy „Maximum”, KrakówRzym 2008, s. 88-98.

\section{Sylwia Grzeszna}

\section{Why Cain? The Motive of "Sacrum" in the Early Poems of Marcin Świetlicki}

\section{(Summary)}

The article is a part of one chapter of a doctoral dissertation. I described the ways of using the motive of "sacrum" in literary works of poets debuting in the 1990s.

Marcin Świetlicki, Tadeusz Różewicz as well as chosen by me Jacek Podsiadło refer in their poems to a modern formula of spirituality in which using the religious motives serves as a means of maintaining contact with a reader that is raised in particular tradition. In an analysis of Świetlicki's literary works I take into consideration texts indicating the search of own discourse of one of the representatives of the so-called "BruLion" generation, as well as the possibility of religious conditioning of provocative gestures of the author of "Zimne Kraje."

Keywords: analysis of newest poetry; association of literature and religion; the motive of sacrum

Słowa kluczowe: analiza poezji najnowszej, związek literatury z religią, motyw sacrum. 